\title{
Herbicide selectivity in the early development of Alexander palm and peach palm
}

\section{Seletividade de herbicidas no desenvolvimento inicial de palmeira- real australiana e palmeira pupunha}

\author{
Juliana Roberta Gobi Queiroz ${ }^{1 *}$; Antonio Carlos Silva Junior ${ }^{2}$; \\ Maria Renata Rocha Pereira ${ }^{3}$; Dagoberto Martins ${ }^{4}$
}

\begin{abstract}
Herbicides are an efficient weed-control method, and herbicide selectivity with regard to palm species is an important subject of agricultural research. Owing to a lack of studies in the literature regarding the use of herbicides on palm trees, especially during the early stages of growth, the present study aimed to evaluate the selectivity of some herbicides during the early development of Alexander palm (Archontophoenix alexandrae) and peach palm (Bactris gasipaes) seedlings. The study was conducted in two seasons in a completely randomized design with eight treatments and four repetitions. The herbicide treatments and dosages (g i.a. ha ${ }^{-1}$ ), were as follows: fluazifop-p-butyl (93.8), sethoxydim (184.0), quizalofop-p-ethyl (75.0) clethodim + fenoxaprop-p-ethyl $(50.0+50.0)$, fomesafen (225.0), lactofen (168.0), and nicosulfuron (50.0), and a no-herbicide control was included. The seedlings of both types of trees were transplanted into 3.1-L plastic containers. In the first study, herbicide was applied to Alexander palm seedlings of $25-30 \mathrm{~cm}$ in height. In the second study, herbicide was applied to Alexander palm seedlings of $30-40 \mathrm{~cm}$ in height. Herbicide was applied to peach palm tree seedlings of $40-55 \mathrm{~cm}$ in height in both studies. In peach palms only, the herbicides caused slight visible damage during early development. Collectively, the results suggested that all herbicides used are selective and can be used on peach palms during the various stages of development when there are one to four leaves. For Alexander palms, fluazifop-p-butyl, quizalofop-p-ethyl, and lactofen were the only herbicides that did not affect early development during the stages when the plant had one to four leaves.
\end{abstract}

Key words: Archentophoenix alexandrae. Bactris gasipaes. Phytotoxicity. Seedlings. Ornamental. Palm heart.

\section{Resumo}

O uso de herbicidas destaca-se como método eficiente no controle de plantas daninhas e a seletividade destes às espécies de palmeira é um aspecto importante a ser avaliado. Devido à escassez de trabalhos na literatura com relação ao uso de herbicidas em palmeiras, principalmente para os estágios iniciais de crescimento, este estudo teve como objetivo avaliar a seletividade de alguns herbicidas no desenvolvimento inicial de mudas de palmeira-real australiana (Archentophoenix alexandrae) e de palmeira pupunha (Bactris gasipaes). O estudo foi conduzido em duas épocas, em delineamento

\footnotetext{
${ }^{1}$ Discente de Doutorado em Agricultura, Faculdade de Ciências Agronômicas, Universidade Estadual Paulista Júlio de Mesquita Filho, FCA/UNESP, Botucatu, SP, Brasil. E-mail: jugobiagro@gmail.com

2 Discente de Doutorado em Produção Vegetal, Faculdade de Ciências Agrárias e Veterinárias, FCAV/UNESP, Jaboticabal, SP, Brasil. E-mail: acsjr_agro@hotmail.com

${ }^{3}$ Prof $^{\mathrm{a}}$ Dra $^{\mathrm{a}}$, Faculdade de Tecnologia, FATEC, Capão Bonito, SP, Brasil. E-mail: mariarenatarp@hotmail.com

${ }^{4}$ Prof. Dr., Departamento de Produção Vegetal, Faculdade de Ciências Agrárias e Veterinárias, FCAV/UNESP, Jaboticabal, SP, Brasil.E-mail: dmartins@fcav.unesp.br

* Author for correspondence
} 
experimental inteiramente casualizado, com oito tratamentos e quatro repetições. Os tratamentos foram herbicidas e doses, em g i.a. ha ${ }^{-1}$ : fluazifop-p-butyl $(93,8)$, sethoxydim $(184,0)$, quizalofop-p-ethyl $(75,0)$, clethodim + fenoxaprop-p-ethyl $(50,0+50,0)$, fomesafen $(225,0)$, lactofen $(168,0)$, nicosulfuron $(50,0)$ e testemunha sem aplicação de herbicida. As mudas de ambas as palmeiras foram transplantadas para vasos plásticos de 3,1L. A aplicação foi realizada sobre mudas de palmeira-real australiana com 25 a $30 \mathrm{~cm}$ de estatura no primeiro estudo e 30 a $40 \mathrm{~cm}$ no segundo estudo e em mudas da palmeira pupunha com 40 a $55 \mathrm{~cm}$ nos dois estudos. Os herbicidas causaram leves injúrias visuais durante o desenvolvimento inicial apenas nas plantas de palmeira pupunha. Todos os herbicidas utilizados foram seletivos e podem ser utilizados para a palmeira pupunha nos estádios de desenvolvimento de 1 a 4 folhas. Para a palmeira-real australiana apenas fluazifop-p-butyl, quizalofop-p-ethyl e lactofen não afetaram o desenvolvimento inicial nos estádios de desenvolvimento de 1 a 4 folhas.

Palavras-chave: Archentophoenix alexandrae. Bactris gasipaes. Fitotoxicidade. Mudas. Ornamental. palmiteiro.

\section{Introduction}

Palm trees have high ornamental value and are widely used in landscaping. They also have considerable economic importance as a food source and for providing raw material for the fiber industry and for oils, beverages, and wax.

The Alexander palm (Archontophoenix alexandrae, Wendl. \& Drude) is originally from the western coast of Australia and is used worldwide for ornamental purposes; it is also considered to be an excellent source of palm heart (UZZO et al., 2004). This species has adapted well to the environmental conditions of Brazil; it has advantageous qualities such as early maturation and hardiness, and its palm heart has a good flavor (FRASSON; LOPES, 2002). Peach palm (Bactris gasipaes, Kunth) can also be used to meet domestic and international demand for palm heart due to its desirable characteristics of ease of cultivation and the high quality of palm heart it produces.

When grown under suitable conditions, peach palm grows rapidly, is hardy, produces good-quality palm heart, and has adequate tillering, which makes it a focus for intensive research and development for cultivation in various tropical areas of the Americas (ANEFALOS et al., 2010). Adverse biotic and abiotic effects have occurred for various reasons, including the expansion of palm heart cultivation in several regions of Brazil, the possibility of planting throughout the year (including during unfavorable times), the high demand for seedlings, and inappropriate management practices during seedling production (SANTOS et al., 2007). The presence of weeds in a crop can reduce growth and productivity. In this case, as palm trees have a poorly developed root system (GARCIA; FONSECA, 1991), which is also delicate and superficial (FERREIRA et al., 1995; LOPES et al., 2014), weed control through plowing, disking, or manual cultivation can cause damage to the plants (OLIVEIRA JÚNIOR et al., 2005).

Thus, the use of herbicides stands out as an efficient method of weed control. Herbicide selectivity, with regard to these species, is an important aspect to be evaluated in the management of the plants, both with regard to development and aesthetic quality, when the plants are intended for ornamental use. Therefore, the present study aimed to evaluate herbicide selectivity in the early development of Alexander palm seedlings and peach palm seedlings.

\section{Material and Methods}

The study was initiated and conducted in a greenhouse at FCA/UNESP, Botucatu campus, São Paulo, in a completely randomized design with eight treatments and four repetitions over two seasons. Herbicide was applied to Alexander palm seedlings (A. alexandrae) of $25-0 \mathrm{~cm}$ in height (1-year and 4-months old) in the first study, which took place in April 2013. The Alexander palm seedlings were 30$40 \mathrm{~cm}$ in height at the time of the second study (1- 
year and 10-months-old) in October 2013. During both years of the study, herbicide was applied to the peach palm seedlings (B. gasipaes), which varied from $40-5 \mathrm{~cm}$ in height. The peach palm seedlings were 1-year and 5-months-old at the time of the first study, and were 1-year and 11-monthsold at the time of the second study. Seedlings were transplanted to plastic containers with a capacity of $3.1 \mathrm{~L}$, which were filled with soil classified as Red-Yellow Latosol (EMBRAPA, 2013). Fertilizer was added based on the results of soil analysis (AGUIAR et al., 2014). The treatments consisted of the following herbicides in the following dosages (g i.a. ha-1): fluazifop-p-butyl (93.8), sethoxydim (184.0), quizalofop-p-ethyl (75.0), clethodim + fenoxaprop- p-ethyl $(50.0+50.0)$, fomesafen (225.0), lactofen (168.0), nicosulfuron (50.0), and an untreated control. ASSIST adjuvant was used with sethoxydim herbicide, according to manufacturer's recommendations. The package inserts of the other treatment used in this study do not recommend the application of an adjuvant in the form of spray.

To apply the herbicides, a pressurized $\mathrm{CO}_{2}$ backpack sprayer was used, equipped with spray nozzles Teejet XR 11002VS flat fan, spaced $50 \mathrm{~cm}$ apart, under a constant working pressure of $200 \mathrm{kPa}$, which provided a spray volume of $200 \mathrm{~L} \mathrm{ha}^{-1}$. The environmental conditions at the time of application were as follows: temperature of $27^{\circ} \mathrm{C}, 72 \%$ relative humidity, and $1.8 \mathrm{~m} \mathrm{~s}^{-1}$ winds during the first study, and $24^{\circ} \mathrm{C}, 60 \%$ relative humidity, and winds of $1 \mathrm{~m}$ $\mathrm{S}^{-1}$ during the second study.

Phytotoxicity was visually assessed at 7, 14, $21,28,35,42$, and 49 days after spraying (DAS), using a rating scale from SBCPD (1995), where ' 0 ' corresponds to no injury observed in the plants and ' 100 ' corresponds to plant death. The following were also evaluated: plant height (from the base to the apex of the top leaf, completely unfurled), the number of fully unfurled leaves, and the dry mass of shoots at the end of each study. For the peach palm, the dry mass of shoots was collected at 49 DAS (first study) and 42 DAS (second study), and for the Alexander palm it was collected at 42
DAS (first and second studies). The results were submitted to analysis of variance using the F test, and the treatment means were compared using the $t$-test at $5 \%$ probability.

\section{Results and Discussion}

In the first study, all herbicides caused mild symptoms of injury to peach palm (B. gasipaes) plants at 14 DAS. Fomesafen was the most phytotoxic to peach palm, and its application resulted in the development of white spots on the younger leaves (Table 1).

For most herbicides, the symptoms dissipated over time. At 42 DAS, only plants treated with sethoxydim and fomesafen herbicides still showed slight damage to the leaves. However, by the end of the study, at 49 DAS, signs of damage had dissipated in response to all the chemical treatments tested (Table 1).

In the second study, no visual signs of damage were observed in the peach palm plants, so a score of zero was assigned to all herbicides. This result might have been related to the age of the seedlings used in the second study, which were a little older.

Queiroz et al. (2016) evaluated the selectivity of herbicides in Euterpes oleracea (açaí palm) seedlings, using the same herbicides as the present study, and found that although the plants showed mild signs of damage, these were no longer observed at $49 \mathrm{DAS}$, as was found in the present study.

In another study investigating the selectivity of herbicides used on native species, Brancalion et al. (2009) observed that sethoxydim was selective for Euterpe edulis palms (called "Palmeira juçara" in common Brazilian Portuguese) and Syagrus romanzoffiana palms (called "Palmeira jerivá" in common Brazilian Portuguese), which corroborates the data observed herein. In the case of sethoxydim, selectivity may be related to enzymatic insensitivity, which constitutes the main selectivity mechanism of acetyl-coenzyme A carboxylase inhibitors (ACCase) (LÓPEZ-OVEJERO et al., 2008). 
Table 1. Percentage of visual phytotoxicity in Bactris gasipaes plants after the application of various herbicides. Botucatu/SP, 2013 (first study).

\begin{tabular}{|c|c|c|c|c|c|c|c|c|}
\hline \multirow{3}{*}{ Treatments } & \multirow{3}{*}{$\begin{array}{l}\text { Doses } \\
\left(\mathrm{g} \mathrm{ha}^{-1}\right)\end{array}$} & \multicolumn{7}{|c|}{ Phytotoxicity (\%) } \\
\hline & & 7 & 14 & 21 & 28 & 35 & 42 & 49 \\
\hline & & \multicolumn{7}{|c|}{------------------------- DAS } \\
\hline 1. fluazifop-p-butyl & 93.8 & 0.0 & $1.5 \mathrm{c}$ & $3.3 \mathrm{c}$ & $3.0 \mathrm{c}$ & $2.0 \mathrm{c}$ & $0.0 \mathrm{c}$ & 0.0 \\
\hline 2. sethoxydim ${ }^{2}$ & 184 & 0.0 & $3.5 \mathrm{~b}$ & $6.3 \mathrm{~b}$ & $7.5 \mathrm{a}$ & $5.8 \mathrm{~b}$ & $1.0 \mathrm{~b}$ & 0.0 \\
\hline 3. quizalofop-p-ethyl & 75 & 0.0 & $3.3 \mathrm{~b}$ & $4.5 \mathrm{c}$ & $4.5 \mathrm{~b}$ & $3.3 \mathrm{c}$ & $0.0 \mathrm{c}$ & 0.0 \\
\hline 4. $(\text { clethodim }+ \text { fenox. })^{3}$ & $50+50$ & 0.0 & $3.0 \mathrm{~b}$ & $3.5 \mathrm{c}$ & $3.0 \mathrm{c}$ & $2.5 \mathrm{c}$ & $0.0 \mathrm{c}$ & 0.0 \\
\hline 5. fomesafen & 225 & 0.0 & $7.5 \mathrm{a}$ & $9.0 \mathrm{a}$ & $8.0 \mathrm{a}$ & $8.0 \mathrm{a}$ & $1.8 \mathrm{a}$ & 0.0 \\
\hline 6. lactofen & 168 & 0.0 & $2.8 \mathrm{~b}$ & $4.0 \mathrm{c}$ & $3.0 \mathrm{c}$ & $3.0 \mathrm{c}$ & $0.0 \mathrm{c}$ & 0.0 \\
\hline 7. nicosulfuron & 50 & 0.0 & $2.8 \mathrm{~b}$ & $4.0 \mathrm{c}$ & $2.8 \mathrm{c}$ & $2.5 \mathrm{c}$ & $0.0 \mathrm{c}$ & 0.0 \\
\hline 8. Control & - & - & - & - & - & - & - & - \\
\hline F treatment & & - & $22.64^{*}$ & $18.01^{*}$ & $15.23^{*}$ & $26.18^{*}$ & $15.18^{*}$ & - \\
\hline CV $(\%)^{4}$ & & - & 22.9 & 19.6 & 22.8 & 22.3 & 92.1 & - \\
\hline $\mathrm{LSD}^{5}$ & & - & 1.18 & 1.42 & 1.35 & 1.26 & 0.53 & - \\
\hline
\end{tabular}

Means followed by the same letter on the column do not differ significantly between the different treatment by $\boldsymbol{t}$ test (P $\leq 0.05$ ); ${ }^{1}$ DAS - Days After Spraying; ${ }^{2}$ Added mineral oil ASSIST $\left(1.0 \mathrm{~L} \mathrm{ha}^{-1}\right) ;{ }^{3}$ (clethodim + fenoxaprop-p-ethyl); ${ }^{4}$ Coefficient of variation; ${ }^{5}$ LSD - Least Significant Difference; *significant at level $(\mathrm{p}<0.05)$.

Similarly, for Alexander palm, no visual signs of damage or phytotoxicity were observed up to 42 DAS. These results corroborate the findings reported by Oliveira Júnior et al. (2005), who found that the herbicides fluazifop-p-butyl, nicosulfuron, and sethoxydim were also visually selective for peach palm seedlings. In this context, the selectivity of PROTOX inhibitor herbicides in tolerant species can be attributed to either poor absorption and translocation of the herbicide, herbicide sequestration, or increased concentration of the PROTOX mitochondrial enzyme (HIGGINS et al., 1988; MATSUMOTO et al., 1999; WARABI et al., 2001). Furthermore, the selectivity of herbicides inhibitors of acetolactate synthase (ALS) in some crops is mainly based on the ability of plants to rapidly metabolize the herbicide into non-toxic forms (SWEESTER et al., 1982). The speed of metabolism can vary depending on species, stage of plant development, and environment (SILVA et al., 2006). Therefore, some of these processes probably occurred in palm plants, despite the fact that they did not present visual signs of damage when subjected to the herbicides studied.
Moreover, in the first study, the application of herbicides resulted in no negative effect on height and dry mass of peach palm plants (Table 2). However, the herbicides quizalofop-p-ethyl and nicosulfuron resulted in increased accumulation of shoot dry mass in the first study. A similar result was not observed in the second study (Table 3). Notably, with regard to the herbicide nicosulfuron, in some studies such as that by Silva et al. (2003), it was observed that this herbicide increased the uptake of nitrogen, phosphorus, and potassium in corn leaves. The same herbicide probably also aided the growth and development of the B. gasipaes palm.

In the second study with peach palms in 2014, a negative effect on plant height was observed only for the herbicide sethoxydim; which resulted in the lowest plant height recorded at the end of the study. However, none of the herbicides negatively influenced the accumulation of dry mass in peach palm shoots (Table 3). It is noteworthy that in the second study, the dry mass increased with the application of the herbicides quizalofop-p-ethyl and nicosulfuron. 
Table 2. Effect of various herbicides on height and dry mass of Bactris gasipaes plants. Botucatu/SP, 2013 (first study).

\begin{tabular}{|c|c|c|c|c|c|c|c|c|c|}
\hline \multirow{3}{*}{ Treatments } & \multirow{3}{*}{$\begin{array}{l}\text { Doses } \\
\left(\mathrm{g} \mathrm{ha}^{-1}\right)\end{array}$} & \multicolumn{7}{|c|}{ Height $(\mathrm{cm})$} & \multirow{3}{*}{$\begin{array}{c}\mathrm{DM}^{2} \\
(\mathrm{~g})\end{array}$} \\
\hline & & 7 & 14 & 21 & 28 & 35 & 42 & 49 & \\
\hline & & \multicolumn{7}{|c|}{------------------------- DAS1 ---------------------- } & \\
\hline 1. fluazifop-p-butyl & 93.8 & 54.0 & 55.0 & 55.3 & 55.3 & 55.3 & 55.5 & 55.8 & $4.40 \mathrm{~b}$ \\
\hline 2. sethoxydim 3 & 184 & 53.8 & 53.8 & 54.0 & 54.0 & 54.0 & 54.0 & 54.0 & $5.71 \mathrm{ab}$ \\
\hline 3. quizalofop-p-ethyl & 75 & 53.0 & 53.0 & 53.0 & 53.0 & 53.3 & 53.3 & 53.0 & $5.10 \mathrm{~b}$ \\
\hline 4. $(\text { clethodim }+ \text { fenox. })^{4}$ & $50+50$ & 57.8 & 58.0 & 58.0 & 58.0 & 58.0 & 58.0 & 58.0 & $8.25 \mathrm{a}$ \\
\hline 5. fomesafen & 225 & 50.0 & 50.5 & 50.8 & 50.8 & 50.8 & 50.8 & 50.8 & $5.18 \mathrm{~b}$ \\
\hline 6. lactofen & 168 & 51.8 & 52.3 & 52.5 & 53.5 & 52.5 & 52.0 & 52.0 & $4.68 \mathrm{~b}$ \\
\hline 7. nicosulfuron & 50 & 47.5 & 47.8 & 47.8 & 47.8 & 47.8 & 47.8 & 47.8 & $5.55 \mathrm{ab}$ \\
\hline 8. Control & - & 59.0 & 59.3 & 59.8 & 59.8 & 59.8 & 59.8 & 59.8 & $4.78 \mathrm{~b}$ \\
\hline F treatment & & $0.69^{\text {ns }}$ & $0.71^{\mathrm{ns}}$ & $0.69^{\text {ns }}$ & $0.74^{\mathrm{ns}}$ & $0.72^{\mathrm{ns}}$ & $0.68^{\mathrm{ns}}$ & $0.68^{\mathrm{ns}}$ & $1.64^{*}$ \\
\hline $\mathrm{CV}(\%)^{5}$ & & 17.0 & 16.6 & 17.1 & 17.0 & 16.0 & 17.2 & 17.0 & 34.6 \\
\hline $\mathrm{LSD}^{6}$ & & 13.34 & 13.13 & 13.54 & 13.45 & 12.64 & 13.54 & 13.40 & 2.78 \\
\hline
\end{tabular}

Means followed by the same letter on the column do not differ significantly between the different treatment by $t$ test $(\mathrm{P} \leq 0.05)$; ${ }^{1}$ DAS - Days After Spraying; ${ }^{2}$ Dry Mass; ${ }^{3}$ Added mineral oil ASSIST $\left(1.0 \mathrm{~L} \mathrm{ha}^{-1}\right) ;{ }^{4}$ (clethodim + fenoxaprop-p-ethyl); ${ }^{5} \mathrm{Coefficient}$ of variation; ${ }^{6} \mathrm{LSD}$ - Least Significant Difference. * significant at level $(\mathrm{p}<0.05)$; ns - not significant.

Table 3. Effect of various herbicides on height and dry mass of Bactris gasipaes plants. Botucatu/SP, 2013 (second study).

\begin{tabular}{|c|c|c|c|c|c|c|c|c|}
\hline \multirow{3}{*}{ Treatments } & \multirow{3}{*}{$\begin{array}{l}\text { Doses } \\
\left(\mathrm{g} \mathrm{ha}^{-1}\right)\end{array}$} & \multicolumn{6}{|c|}{ Height $(\mathrm{cm})$} & \multirow{3}{*}{$\begin{array}{c}\mathrm{DM}^{2} \\
(\mathrm{~g})\end{array}$} \\
\hline & & 7 & 14 & 21 & 28 & 35 & 42 & \\
\hline & & \multicolumn{6}{|c|}{ 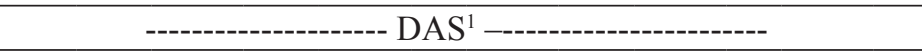 } & \\
\hline 1. fluazifop-p-butyl & 93.8 & $43.6 \mathrm{abc}$ & $44.8 \mathrm{abc}$ & $45.8 \mathrm{bc}$ & $46.4 \mathrm{abc}$ & $46.6 \mathrm{ab}$ & $48.3 \mathrm{ab}$ & $7.03 \mathrm{ab}$ \\
\hline 2. sethoxydim ${ }^{3}$ & 184 & $40.4 \mathrm{c}$ & $41.4 \mathrm{c}$ & $42.1 \mathrm{c}$ & $42.5 \mathrm{c}$ & $43.4 \mathrm{~b}$ & $44.0 \mathrm{~b}$ & $6.62 \mathrm{ab}$ \\
\hline 3. quizalofop-p-ethyl & 75 & $51.1 \mathrm{abc}$ & $52.4 \mathrm{abc}$ & $52.8 \mathrm{bc}$ & $52.8 \mathrm{abc}$ & $53.0 \mathrm{ab}$ & $53.3 \mathrm{ab}$ & $8.15 \mathrm{a}$ \\
\hline 4. $(\text { clethodim }+ \text { fenox. })^{4}$ & $50+50$ & $42.1 \mathrm{c}$ & $44.8 \mathrm{abc}$ & $45.3 \mathrm{bc}$ & $45.4 \mathrm{abc}$ & $45.5 \mathrm{ab}$ & $46.0 \mathrm{ab}$ & $7.01 \mathrm{ab}$ \\
\hline 5. fomesafen & 225 & $55.6 \mathrm{a}$ & $56.1 \mathrm{a}$ & $56.1 \mathrm{a}$ & $56.4 \mathrm{a}$ & $56.4 \mathrm{a}$ & $56.5 \mathrm{a}$ & $5.45 \mathrm{ab}$ \\
\hline 6. lactofen & 168 & $42.1 \mathrm{c}$ & $44.1 \mathrm{bc}$ & $44.9 \mathrm{bc}$ & 44.9 bc & $45.1 \mathrm{ab}$ & $45.6 \mathrm{ab}$ & $5.68 \mathrm{ab}$ \\
\hline 7. nicosulfuron & 50 & $48.3 \mathrm{abc}$ & $48.3 \mathrm{abc}$ & $48.5 \mathrm{bc}$ & $48.5 \mathrm{abc}$ & $48.5 \mathrm{ab}$ & $49.1 \mathrm{ab}$ & $7.81 \mathrm{a}$ \\
\hline 8. Control & - & $54.8 \mathrm{ab}$ & $55.0 \mathrm{ab}$ & $55.0 \mathrm{a}$ & $55.0 \mathrm{ab}$ & $55.3 \mathrm{a}$ & $55.4 \mathrm{a}$ & $5.00 \mathrm{~b}$ \\
\hline F treatment & & $2.47^{*}$ & $2.00^{*}$ & $1.81^{*}$ & $1.81^{*}$ & $1.65^{*}$ & $1.54^{*}$ & $1.41^{*}$ \\
\hline $\mathrm{CV}(\%)^{5}$ & & 16.3 & 16.1 & 15.9 & 15.6 & 15.8 & 15.3 & 28.8 \\
\hline $\mathrm{LSD}^{6}$ & & 11.31 & 11.47 & 11.38 & 11.22 & 11.40 & 11.21 & 2.80 \\
\hline
\end{tabular}

Means followed by the same letter on the column do not differ significantly between the different treatment by $t$ test $(\mathrm{P} \leq 0.05)$; ${ }^{1}$ DAS - Days After Spraying; ${ }^{2}$ Dry Mass; ${ }^{3}$ Added mineral oil ASSIST (1.0 L ha $\left.{ }^{-1}\right) ;{ }^{4}$ (clethodim + fenoxaprop-p-ethyl); ${ }^{5} \mathrm{Coefficient}$ of variation; ${ }^{6} \mathrm{LSD}$ - Least Significant Difference; * significant at level $(\mathrm{p}<0.05)$.

A previous study (QUEIROZ et al., 2016) examined Euterpes edulis (açaí palm) seedlings that were treated with the same herbicides studied herein, and their results showed that sethoxydim did not reduce the height or accumulation of dry mass in plant shoots, as was also observed in the present study.
Regarding the number of unfurled leaves of peach palm plants, both in the first (2013) and second study (2014), no negative effect was observed following the application of the different herbicides tested, regardless of the time of observation (Tables 4 and 5). 
Table 4. Effect of various herbicides on the number of fully unfurled leaves of Bactris gasipaes. Botucatu/SP, 2013 (first study).

\begin{tabular}{|c|c|c|c|c|c|c|c|c|}
\hline \multirow{3}{*}{ Treatments } & \multirow{3}{*}{$\begin{array}{l}\text { Doses } \\
\left(\mathrm{g} \mathrm{ha}^{-1}\right)\end{array}$} & \multicolumn{7}{|c|}{ Number of leaves } \\
\hline & & 7 & 14 & 21 & 28 & 35 & 42 & 49 \\
\hline & & \multicolumn{7}{|c|}{---------------------------------- DAS } \\
\hline 1. fluazifop-p-butyl & 93.8 & 3.5 & 3.5 & 3.5 & 3.5 & 3.5 & 3.5 & 3.5 \\
\hline 2. sethoxydim ${ }^{2}$ & 184 & 3.5 & 3.5 & 3.8 & 3.8 & 3.8 & 3.8 & 3.8 \\
\hline 3. quizalofop-p-ethyl & 75 & 4.0 & 4.0 & 4.3 & 4.3 & 4.3 & 4.3 & 4.3 \\
\hline 4. $(\text { clethodim }+ \text { fenox. })^{3}$ & $50+50$ & 3.5 & 3.5 & 3.5 & 3.5 & 3.5 & 3.5 & 3.5 \\
\hline 5. fomesafen & 225 & 3.5 & 3.5 & 3.5 & 3.5 & 3.5 & 3.5 & 3.5 \\
\hline 6. lactofen & 168 & 3.8 & 3.8 & 3.8 & 3.8 & 3.8 & 3.8 & 3.8 \\
\hline 7. nicosulfuron & 50 & 3.8 & 3.8 & 3.8 & 3.8 & 3.8 & 3.8 & 3.8 \\
\hline 8. Control & - & 3.8 & 3.8 & 3.8 & 3.8 & 3.8 & 3.8 & 3.8 \\
\hline F treatment & & $0.76^{\mathrm{ns}}$ & $0.76^{\mathrm{ns}}$ & $0.68^{\mathrm{ns}}$ & $0.59^{\mathrm{ns}}$ & $0.99^{\mathrm{ns}}$ & $0.14^{\mathrm{ns}}$ & $0.14^{\mathrm{ns}}$ \\
\hline $\mathrm{CV}(\%)^{4}$ & & 19.4 & 19.4 & 26.4 & 25.5 & 25.0 & 25.4 & 25.4 \\
\hline $\mathrm{LSD}^{5}$ & & 1.10 & 1.10 & 1.47 & 1.43 & 1.36 & 1.38 & 1.38 \\
\hline
\end{tabular}

${ }^{1}$ DAS - Days After Spraying; ${ }^{2}$ Added mineral oil ASSIST $\left(1.0 \mathrm{~L} \mathrm{ha}^{-1}\right) ;{ }^{3}$ (clethodim + fenoxaprop-p-ethyl); ${ }^{4}$ Coefficient of variation; ${ }^{5}$ LSD - Least Significant Difference; ns - not significant.

Table 5. Effect of various herbicides on the number of fully unfurled leaves of Bactris gasipaes. Botucatu/SP, 2013 (second study).

\begin{tabular}{|c|c|c|c|c|c|c|c|}
\hline \multirow{3}{*}{ Treatments } & \multirow{3}{*}{$\begin{array}{l}\text { Doses } \\
\left(\mathrm{g} \mathrm{ha}^{-1}\right)\end{array}$} & \multicolumn{6}{|c|}{ Number of leaves } \\
\hline & & 7 & 14 & 21 & 28 & 35 & 42 \\
\hline & & \multicolumn{6}{|c|}{--------------------------- DAS } \\
\hline 1. fluazifop-p-butyl & 93.8 & 2.0 & 2.3 & 2.3 & 2.8 & 2.8 & 3.0 \\
\hline 2. sethoxydim ${ }^{2}$ & 184 & 2.0 & 2.3 & 2.3 & 2.3 & 2.8 & 3.0 \\
\hline 3. quizalofop-p-ethyl & 75 & 1.8 & 2.5 & 2.5 & 2.5 & 2.8 & 3.0 \\
\hline 4. $(\text { clethodim }+ \text { fenox. })^{3}$ & $50+50$ & 2.0 & 2.5 & 2.5 & 3.0 & 3.0 & 3.0 \\
\hline 5. fomesafen & 225 & 4.3 & 4.3 & 4.3 & 4.3 & 4.3 & 5.0 \\
\hline 6. lactofen & 168 & 1.5 & 1.8 & 2.0 & 2.0 & 2.3 & 2.5 \\
\hline 7. nicosulfuron & 50 & 1.5 & 1.8 & 1.8 & 2.0 & 2.0 & 2.3 \\
\hline 8. Control & - & 3.8 & 3.8 & 3.8 & 3.8 & 4.3 & 4.5 \\
\hline F treatment & & $15.7^{\mathrm{ns}}$ & $6.13^{\mathrm{ns}}$ & $8.15^{\text {ns }}$ & $6.04^{\text {ns }}$ & $7.55^{\text {ns }}$ & $7.79^{\text {ns }}$ \\
\hline $\mathrm{CV}(\%)^{4}$ & & 22.6 & 27.9 & 23.1 & 23.8 & 20.3 & 20.9 \\
\hline $\mathrm{LSD}^{5}$ & & 2.84 & 2.62 & 2.90 & 2.98 & 2.89 & 2.77 \\
\hline
\end{tabular}

${ }^{1}$ DAS - Days After Spraying; ${ }^{2}$ Added mineral oil ASSIST $\left(1.0 \mathrm{~L} \mathrm{ha}^{-1}\right) ;{ }^{3}$ (clethodim + fenoxaprop-p-ethyl); ${ }^{4}$ Coefficient of variation; ${ }^{5}$ LSD - Least Significant Difference; ns - not significant.

Visually, none of the herbicides caused damage to Alexander palm seedlings in either study, so a score of zero was assigned for all evaluation periods. As for height and accumulation of dry mass in the shoots of Alexander palms, no negative effect was observed in the first study (Table 6). However, in the second study, the application of sethoxydim herbicide had a negative effect on plant height at the end of the evaluation (Table 7), which was also found with $B$. gasipaes in the second study (Table 3). The use of sethoxydim herbicide, along with (clethodim + fenoxaprop-p-ethyl), resulted in decreased accumulation of shoot dry mass (Table 7 ), which was not observed in the first study (Table 6). These negative results, depending on the season and species, suggest that there is a need for further studies on the safe use of these herbicides for these species of palm tree. 
Table 6. Effect of various herbicides on height and dry mass of Archontophoenix alexandrae plants. Botucatu/SP, 2013 (first study).

\begin{tabular}{|c|c|c|c|c|c|c|c|c|}
\hline \multirow{3}{*}{ Treatments } & \multirow{3}{*}{$\begin{array}{l}\text { Doses } \\
\left(\mathrm{g} \mathrm{ha}^{-1}\right)\end{array}$} & \multicolumn{6}{|c|}{ Height $(\mathrm{cm})$} & \multirow{3}{*}{$\begin{array}{c}\mathrm{DM}^{2} \\
(\mathrm{~g})\end{array}$} \\
\hline & & 7 & 14 & 21 & 28 & 35 & 42 & \\
\hline & & \multicolumn{6}{|c|}{--------------------- DAS } & \\
\hline 1. fluazifop-p-butyl & 93.8 & $26.1 \mathrm{~b}$ & $27.3 \mathrm{~b}$ & $27.8 \mathrm{~b}$ & $28.6 \mathrm{~b}$ & $29.8 \mathrm{~b}$ & $31.0 \mathrm{~b}$ & $2.48 \mathrm{c}$ \\
\hline 2. sethoxydim ${ }^{3}$ & 184 & $29.0 \mathrm{ab}$ & $29.5 \mathrm{ab}$ & $29.5 \mathrm{ab}$ & $29.5 \mathrm{~b}$ & $30.5 \mathrm{~b}$ & $33.1 \mathrm{ab}$ & $2.93 \mathrm{bc}$ \\
\hline 3. quizalofop-p-ethyl & 75 & $28.1 \mathrm{ab}$ & $29.3 \mathrm{ab}$ & $29.6 \mathrm{ab}$ & $29.6 \mathrm{~b}$ & $30.0 \mathrm{~b}$ & $31.1 \mathrm{~b}$ & $3.01 \mathrm{bc}$ \\
\hline 4. $(\text { clethodim }+ \text { fenox. })^{4}$ & $50+50$ & $28.6 \mathrm{ab}$ & $28.9 \mathrm{ab}$ & $29.3 \mathrm{ab}$ & $29.3 \mathrm{~b}$ & $30.5 \mathrm{~b}$ & $32.3 \mathrm{ab}$ & $3.23 \mathrm{abc}$ \\
\hline 5. fomesafen & 225 & $30.6 \mathrm{a}$ & $31.4 \mathrm{a}$ & $32.4 \mathrm{a}$ & $34.1 \mathrm{a}$ & $35.3 \mathrm{a}$ & $36.5 \mathrm{a}$ & $3.94 \mathrm{ab}$ \\
\hline 6. lactofen & 168 & $26.5 \mathrm{~b}$ & $27.5 \mathrm{ab}$ & $29.3 \mathrm{ab}$ & $31.1 \mathrm{ab}$ & $31.9 \mathrm{ab}$ & $32.1 \mathrm{ab}$ & $2.75 \mathrm{c}$ \\
\hline 7. nicosulfuron & 50 & $30.9 \mathrm{a}$ & $30.9 \mathrm{ab}$ & $31.1 \mathrm{ab}$ & $31.4 \mathrm{ab}$ & $31.5 \mathrm{ab}$ & $32.4 \mathrm{ab}$ & $4.23 \mathrm{a}$ \\
\hline 8. Control & - & $27.9 \mathrm{ab}$ & $29.6 \mathrm{ab}$ & $30.1 \mathrm{ab}$ & $30.9 \mathrm{ab}$ & $31.0 \mathrm{~b}$ & $31.8 \mathrm{~b}$ & $3.05 \mathrm{bc}$ \\
\hline F treatment & & $1.60^{*}$ & $1.22^{*}$ & $1.03^{*}$ & $1.63^{*}$ & $1.49^{*}$ & $1.25^{*}$ & $2.55^{*}$ \\
\hline $\mathrm{CV}(\%)^{5}$ & & 9.5 & 9.1 & 9.4 & 9.1 & 9.2 & 9.6 & 23.3 \\
\hline $\mathrm{LSD}^{6}$ & & 3.99 & 3.88 & 4.13 & 4.07 & 4.22 & 4.59 & 1.10 \\
\hline
\end{tabular}

Means followed by the same letter on the column do not differ significantly between the different treatment by $\boldsymbol{t}$ test $(\mathrm{P} \leq 0.05)$; ${ }^{1}$ DAS - Days After Spraying; ${ }^{2}$ Dry Mass; ${ }^{3}$ Added mineral oil ASSIST $\left(1.0 \mathrm{~L} \mathrm{ha}^{-1}\right) ;{ }^{4}$ (clethodim + fenoxaprop-p-ethyl); ${ }^{5} \mathrm{Coefficient}$ of variation; ${ }^{6} \mathrm{LSD}$ - Least Significant Difference; * significant at level $(\mathrm{p}<0.05)$.

Table 7. Effect of various herbicides on height and dry mass of Archontophoenix alexandrae plants. Botucatu/SP, 2013 (second study).

\begin{tabular}{|c|c|c|c|c|c|c|c|c|}
\hline \multirow{3}{*}{ Treatments } & \multirow{3}{*}{$\begin{array}{l}\text { Doses } \\
\left(\mathrm{g} \mathrm{ha}^{-1}\right)\end{array}$} & \multicolumn{6}{|c|}{ Height $(\mathrm{cm})$} & \multirow{3}{*}{$\begin{array}{c}\mathrm{DM}^{2} \\
(\mathrm{~g})\end{array}$} \\
\hline & & 7 & 14 & 21 & 28 & 35 & 42 & \\
\hline & & \multicolumn{6}{|c|}{ 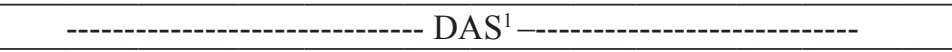 } & \\
\hline 1. fluazifop-p-butyl & 93.8 & $44.5 \mathrm{a}$ & $45.4 \mathrm{a}$ & $46.9 \mathrm{a}$ & $47.0 \mathrm{a}$ & $47.0 \mathrm{a}$ & $47.3 \mathrm{a}$ & $8.02 \mathrm{ab}$ \\
\hline 2. sethoxydim ${ }^{3}$ & 184 & $33.0 \mathrm{~b}$ & $33.6 \mathrm{~b}$ & $33.5 \mathrm{~b}$ & $33.6 \mathrm{~b}$ & $34.1 \mathrm{~b}$ & $34.8 \mathrm{~b}$ & $6.04 \mathrm{~b}$ \\
\hline 3. quizalofop-p-ethyl & 75 & $39.5 \mathrm{ab}$ & $40.6 \mathrm{ab}$ & $43.5 \mathrm{ab}$ & $44.0 \mathrm{ab}$ & $44.3 \mathrm{ab}$ & $45.6 \mathrm{ab}$ & $6.55 \mathrm{ab}$ \\
\hline 4. $(\text { cleth. }+ \text { fenox. })^{4}$ & $50+50$ & $37.1 \mathrm{ab}$ & $37.1 \mathrm{ab}$ & $37.9 \mathrm{ab}$ & $38.0 \mathrm{ab}$ & $38.4 \mathrm{ab}$ & $38.9 \mathrm{ab}$ & $5.97 \mathrm{~b}$ \\
\hline 5. fomesafen & 225 & $38.8 \mathrm{ab}$ & $38.5 \mathrm{ab}$ & $38.9 \mathrm{ab}$ & $39.1 \mathrm{ab}$ & $39.9 \mathrm{ab}$ & $40.9 \mathrm{ab}$ & $7.01 \mathrm{ab}$ \\
\hline 6. lactofen & 168 & $40.6 \mathrm{ab}$ & $40.9 \mathrm{ab}$ & $41.3 \mathrm{ab}$ & $41.3 \mathrm{ab}$ & $41.4 \mathrm{ab}$ & $41.3 \mathrm{ab}$ & $7.02 \mathrm{ab}$ \\
\hline 7. nicosulfuron & 50 & $37.8 \mathrm{ab}$ & $38.3 \mathrm{ab}$ & $38.5 \mathrm{ab}$ & $38.5 \mathrm{ab}$ & $38.3 \mathrm{ab}$ & $38.3 \mathrm{ab}$ & $6.55 \mathrm{ab}$ \\
\hline 8. Control & - & $45.8 \mathrm{a}$ & $46.3 \mathrm{a}$ & $47.0 \mathrm{a}$ & $47.4 \mathrm{a}$ & $48.4 \mathrm{a}$ & $49.3 \mathrm{a}$ & $9.50 \mathrm{a}$ \\
\hline F treatment & & $1.65^{*}$ & $1.50^{*}$ & $1.60^{*}$ & $1.64^{*}$ & $1.64^{*}$ & $1.61^{*}$ & $1.09^{*}$ \\
\hline $\mathrm{CV}(\%)^{5}$ & & 16.1 & 17.1 & 18.1 & 18.1 & 18.1 & 18.6 & 31.7 \\
\hline $\mathrm{LSD}^{6}$ & & 9.29 & 10.00 & 10.82 & 10.84 & 10.97 & 11.38 & 3.28 \\
\hline
\end{tabular}

Means followed by the same letter on the column do not differ significantly between the different treatment by $t$ test $(\mathrm{P} \leq 0.05)$; ${ }^{1} \mathrm{DAS}$ - Days After Spraying; ${ }^{2}$ Dry Mass; ${ }^{3}$ Added mineral oil ASSIST $\left(1.0 \mathrm{~L} \mathrm{ha}{ }^{-1}\right) ;{ }^{4}$ (clethodim + fenoxaprop-p-ethyl); ${ }^{5}$ Coefficient of variation; ${ }^{6} \mathrm{LSD}$ - Least Significant Difference; *significant at level $(\mathrm{p}<0.05)$.

With respect to the Alexander palm, in the first study no deleterious effect on the number of leaves was found to result from the application of different herbicides (Table 8). However, in the second study, a negative effect was observed on the growth of Alexander palm leaves with the application of the herbicides sethoxydim, (clethodim + fenoxaprop-pethyl), and nicosulfuron (Table 9). 
Table 8. Effect of various herbicides on the number of fully unfurled leaves of Archontophoenix alexandrae. Botucatu/ SP, 2013 (first study).

\begin{tabular}{|c|c|c|c|c|c|c|c|}
\hline \multirow{3}{*}{ Treatments } & \multirow{3}{*}{$\begin{array}{l}\text { Doses } \\
\left(\mathrm{g} \mathrm{ha}^{-1}\right)\end{array}$} & \multicolumn{6}{|c|}{ Number of leaves } \\
\hline & & 7 & 14 & 21 & 28 & 35 & 42 \\
\hline & & \multicolumn{6}{|c|}{---------------------- DAS } \\
\hline 1. fluazifop-p-butyl & 93.8 & 4.0 & 4.0 & 4.3 & 4.3 & 4.3 & 4.3 \\
\hline 2. sethoxydim ${ }^{2}$ & 184 & 4.3 & 4.0 & 4.0 & 4.5 & 4.8 & 4.8 \\
\hline 3. quizalofop-p-ethyl & 75 & 4.0 & 4.0 & 4.0 & 4.0 & 4.0 & 4.3 \\
\hline 4. clethodim + fenoxaprop-p-ethyl & $50+50$ & 4.0 & 4.0 & 4.0 & 4.0 & 4.0 & 4.3 \\
\hline 5. fomesafen & 225 & 4.0 & 4.3 & 4.5 & 4.8 & 4.8 & 5.0 \\
\hline 6. lactofen & 168 & 3.8 & 4.5 & 4.5 & 4.5 & 4.5 & 4.5 \\
\hline 7. nicosulfuron & 50 & 3.8 & 3.8 & 3.8 & 4.3 & 4.3 & 4.3 \\
\hline 8. Control & - & 4.3 & 4.3 & 4.3 & 4.3 & 4.3 & 4.5 \\
\hline F treatment & & $0.28^{\text {ns }}$ & $1.18^{\mathrm{ns}}$ & $1.53^{\mathrm{ns}}$ & $0.59^{\text {ns }}$ & $0.33^{\text {ns }}$ & $0.90^{\text {ns }}$ \\
\hline $\mathrm{CV}(\%)^{3}$ & & 17.9 & 12.9 & 11.9 & 15.4 & 16.6 & 15.3 \\
\hline $\mathrm{LSD}^{4}$ & & 1.05 & 0.76 & 0.70 & 0.96 & 1.05 & 1.00 \\
\hline
\end{tabular}

${ }^{1} \mathrm{DAS}$ - Days After Spraying; ${ }^{2}$ Added mineral oil ASSIST $\left(1.0 \mathrm{~L} \mathrm{ha}^{-1}\right) ;{ }^{3} \mathrm{Coefficient} \mathrm{of} \mathrm{variation;}{ }^{4} \mathrm{LSD}$ - Least Significant Difference; ns - not significant.

Table 9. Effect of various herbicides on the number of fully unfurled leaves of Archontophoenix alexandrae. Botucatu/ SP, 2013 (second study).

\begin{tabular}{|c|c|c|c|c|c|c|c|}
\hline \multirow{3}{*}{ Treatments } & \multirow{3}{*}{$\begin{array}{l}\text { Doses } \\
\left(\mathrm{g} \mathrm{ha}^{-1}\right)\end{array}$} & \multicolumn{6}{|c|}{ Number of leaves } \\
\hline & & 7 & 14 & 21 & 28 & 35 & 42 \\
\hline & & \multicolumn{6}{|c|}{ 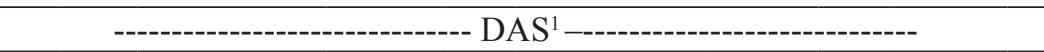 } \\
\hline 1. fluazifop-p-butyl & 93.8 & $4.0 \mathrm{a}$ & $4.3 \mathrm{a}$ & $4.3 \mathrm{a}$ & 4.3 & $4.5 \mathrm{a}$ & $4.3 \mathrm{ab}$ \\
\hline 2. sethoxydim ${ }^{2}$ & 184 & $3.5 \mathrm{ab}$ & $3.5 \mathrm{ab}$ & $3.5 \mathrm{ab}$ & 3.8 & $3.8 \mathrm{ab}$ & $3.8 \mathrm{bc}$ \\
\hline 3. quizalofop-p-ethyl & 75 & $3.5 \mathrm{ab}$ & $3.5 \mathrm{ab}$ & $3.8 \mathrm{ab}$ & 3.8 & $4.0 \mathrm{ab}$ & $4.3 \mathrm{ab}$ \\
\hline 4. $(\text { cleth. }+ \text { fenox. })^{3}$ & $50+50$ & $3.5 \mathrm{ab}$ & $3.5 \mathrm{ab}$ & $3.5 \mathrm{ab}$ & 3.5 & $3.8 \mathrm{ab}$ & $3.8 \mathrm{bc}$ \\
\hline 5. fomesafen & 225 & $3.0 \mathrm{~b}$ & $3.0 \mathrm{~b}$ & $3.0 \mathrm{~b}$ & 3.5 & $3.8 \mathrm{ab}$ & $3.8 \mathrm{bc}$ \\
\hline 6. lactofen & 168 & $3.3 \mathrm{ab}$ & $3.5 \mathrm{ab}$ & $3.5 \mathrm{ab}$ & 3.5 & $3.5 \mathrm{ab}$ & $4.3 \mathrm{ab}$ \\
\hline 7. nicosulfuron & 50 & $3.3 \mathrm{ab}$ & $3.3 \mathrm{ab}$ & $3.3 \mathrm{ab}$ & 3.3 & $3.3 \mathrm{~b}$ & $3.0 \mathrm{c}$ \\
\hline 8. Control & - & $3.8 \mathrm{ab}$ & $3.8 \mathrm{ab}$ & $3.8 \mathrm{ab}$ & 3.8 & $4.3 \mathrm{ab}$ & $4.8 \mathrm{a}$ \\
\hline F treatment & & $1.01^{*}$ & $1.62^{*}$ & $1.11^{*}$ & $0.66^{\mathrm{ns}}$ & $1.30^{*}$ & $2.35^{*}$ \\
\hline $\mathrm{CV}(\%)^{4}$ & & 17.9 & 18.0 & 19.9 & 19.9 & 18.2 & 17.3 \\
\hline $\mathrm{LSD}^{5}$ & & 0.91 & 0.92 & 1.03 & 1.06 & 1.02 & 1.00 \\
\hline
\end{tabular}

Means followed by the same letter on the column do not differ significantly between the different treatment by $\boldsymbol{t}$ test $(\mathrm{P} \leq 0.05$ ); ${ }^{1}$ DAS - Days After Spraying; ${ }^{2}$ Added mineral oil ASSIST $\left(1.0 \mathrm{~L} \mathrm{ha}^{-1}\right) ;{ }^{3}$ (clethodim + fenoxaprop-p-ethyl); ${ }^{4}$ Coefficient of variation; ${ }^{5}$ LSD - Least Significant Difference; *significant at level $(\mathrm{p}<0.05)$; ns - not significant.

As for the herbicides fomesafen and nicosulfuron, regardless of the absence of negative effects on plant height and accumulation of dry mass (Table 7), the reduction in the number of leaves in the second study (2014) raises concerns about its selectivity for Alexander palm (Table 9). Therefore, further studies on these herbicides are still needed in order to gather data on their selectivity with regard to this palm tree species. 


\section{Conclusions}

No visual damage was observed in Alexander palm plants upon treatment with the herbicides tested in this study, whereas peach palms subjected to herbicide treatment in the second study showed evidence of damage. Thus, all herbicides investigated in this study may be viably used for peach palms. The herbicides fluazifop-p-butyl, quizalofop-p-ethyl, and lactofen did not affect the early development of Alexander palm.

\section{References}

AGUIAR, T. E. A.; GONÇALVES, C.; PATERNIANI, M. E. A. Z. G.; TUCCI, M. L. S.; CASTRO, C. E. F. Boletim 200: instruções agrícolas para as principais culturas econômicas. 7. ed. Campinas: IAC, 2014. 452 p.

ANEFALOS, L. C.; MODOLO, V. A.; TUCCI, M. L. S. Economic potential of peach palm cultivation in São Paulo State-Brazil. In: INTERNATIONAL SYMPOSIUM ON GENETIC RESOURCES OF BAMBOOS AND PALMS AND III INTERNATIONAL SYMPOSIUM ON ORNAMENTAL PALMS 1003, 1., 2010, Campinas. Proceeding...ActaHort, 2010 p. 179-184. CD-ROM.

BRANCALION, P. H. S.; ISERNHAGEN, I.; MACHADO, R. P.; CHRISTOFFOLETI, P. J.; RODRIGUES, R. R. Seletividade dos herbicidas setoxidim, isoxaflutol e bentazon a espécies arbóreas nativas. Pesquisa Agropecuária Brasileira, Brasília, v. 44, n. 3, p. 251-257, 2009.

EMPRESA BRASILEIRA DE PESQUISA AGROPECUÁRIA - EMBRAPA. Centro Nacional de Pesquisa de Solos. Sistema brasileiro de classificação de solos. 3. ed. Rio de Janeiro: EMBRAPA-SPI, 2013. 353 p.

FERREIRA, S. A. N.; CLEMENT, C. R.; RANZANI, S. S. C. Contribuição para o conhecimento do sistema radicular da pupunheira (Bactris gasipaes Kunth, Palmae). II. Solo Latossolo amarelo, textura argilosa. Acta Amazônica, Manaus, v. 25, n. 3, p. 161-170, 1995.

FRASSON, A.; LOPES, J. D. S. Cultivo de palmeirareal para produção de palmito. Viçosa, MG: CPT, 2002. $206 \mathrm{p}$.

GARCIA, T. B.; FONSECA, C. L. Crescimento de mudas de pupunheira em condições de viveiro coberto com palha. Pesquisa Agropecuária Brasileira, Brasília, v. 26, n. 9 , p. $1447-1451,1991$.
HIGGINS, J. M.; WHITWELL, T.; CORBIN, F. T.; CARTER JÚNIOR, G. E.; HILL JÚNIOR, H. S. Absorption, translocation, and metabolism of acifluorfen and lactofen in pitted morningglory (Ipomoea lacunosa) and ivyleaf morningglory (Ipomoea hederaceae). Weed Science, Champaing, v. 36, n. 2, p. 141-145, 1988.

LOPES, A. S.; HERNANDEZ, F. B. T.; ALVES JÚNIOR, J.; OLIVEIRA, G. Q. Distribution of the root system of peach palm under drip irrigation. Acta Scientiarum. Agronomy, Maringá, v. 36, n. 3, p. 317-321, 2014.

LÓPEZ-OVEJERO, R. F.; CARVALHO, S. J. P.; VARGAS, L. Resistência de plantas daninhas aos herbicidas inibidores da ACCase (Grupo A). In: CHRISTOFFOLETI, P. J. (Ed.). Aspectos de resistência de plantas daninhas a herbicidas. 3. ed. Piracicaba: Associação Brasileira de Ação à Resistência de Plantas Daninhas, 2008. p. 50-61.

MATSUMOTO, H.; KASHIMOTO, Y.; WARABI, E. Basis for common chickweed (Stellaria media) tolerance to oxyfluorfen. Pesticide Biochemistry and Physiology, San Diego, v. 64, n. 1, p. 47-53, 1999.

OLIVEIRA JÚNIOR, R. S.; CONSTANTIN, J.; INOUE, M. H.; CARREIRA, S. A. M.; DVORANEN, E. C.; TESSMANN, D. J. Diagnóstico e perspectivas do manejo de plantas daninhas na cultura da pupunha no Noroeste do Estado do Paraná. Acta Scientiarum. Agronomy, Maringá, v. 27, n. 2, p. 335-341, 2005.

QUEIROZ, J. R. G.; SILVA JÚNIOR, A. C.; PEREIRA, M. R. R.; MARTINS, D. Desenvolvimento inicial de mudas de Euterpe ssp. após a aplicação de herbicidas. Revista Brasileira de Fruticultura, Jaboticabal, v. 38, n. 1, p. 72-80, 2016.

SANTOS, A. F. dos; TESMANN, D. J.; VIDA, J. B.; SANTANA, D. L. Q. Manejo fitossanitário em viveiros de palmeiras para palmito. Colombo: EMBRAPA. Centro Nacional de Pesquisa de Florestas, 2007. 9 p. (Circular Técnica, 146).

SILVA, A. F.; JAKELAITIS, A.; SILVA, A. A.; FERREIRA, L. R. Técnicas para viabilização do consórcio milho/Brachiaria brizantha. In: SIMPÓSIO DE INICIAÇÃO CIENTÍFICA, 13., 2003, Viçosa, MG. Anais... Viçosa, MG: UFV, 2003. p. 310.

SILVA, M. A.; CARLIN, S. D.; CAPUTO, M. M. Tipos de colheita e épocas de aplicação de glifosato na erradicação de soqueiras de cana-de-açúcar. Pesquisa Agropecuária Brasileira, Brasília, v. 41, n. 1, p. 43-49, 2006.

SOCIEDADE BRASILEIRA DA CIÊNCIA DAS PLANTAS DANINHAS - SBCPD. Procedimentos para instalação, avaliação e análise de experimentos com herbicidas. Londrina: SBCPD, 1995. 42 p. 
SWEESTER, P. B.; SCHOW, G. S.; HUTCHISON, J. M. Metabolism of chlorsulfuron by plants: biological basis for selectivity of a new herbicide for cereals. Pesticide Biochemistry and Physiology, San Diego, v. 17, n. 1, p. 18-23, 1982.

UZZO, R. P.; BOVI, M. L. A.; SPIERING, S. H.; SÁES, L. A. Coeficiente de caminhamento entre caracteres vegetativos e de produção de palmito da palmeirareal australiana. Horticultura Brasileira, Vitoria da Conquista, v. 22, n. 1, p. 136-142, 2004.
WARABI, E.; USUI, K.; TANAKA, Y.; MATSUMOTO, H. Resistance of a soybean cell line to oxyfluorfen overproduction of mitochondrial protoporphyrinogen oxidase. Pest Management Science, Sussex, v. 57, n. 8, p. 743-748, 2001. 